\title{
DETERMINANTS OF NATIONAL-POLITICAL CONSCIOUSNESS OF MODERN UKRAINIAN SOCIETY
}

\author{
Matviienkiv S. M., Lushahina T. V.
}

\section{INTRODUCTION}

The development of statehood, the formation of its democratic institutions, foreign policy guidelines and domestic political stability directly depends on the level of political consciousness of citizens. And national welfare and security are formed through the stage of self-awareness as a single nation, which is based on the formation of national and political consciousness of citizens. Although the concept of "political consciousness" for political science is not new, but it constantly requires detailed study, as it is inextricably linked with practical political activities, including the ability of citizens to make political decisions from municipal to national level, social dialogue, have not only rights, but also to perform duties. The national-political consciousness of Ukrainian society during the period of independence acquired new features that emerged in the processes of revolutions, disappointments in government institutions and the rise of national-patriotic spirit. Therefore, the relevance of the study of national and political consciousness of modern Ukrainian society is due to the above problems that need to be addressed.

During the period of independence, scholars have been actively discussing what political consciousness really is, especially "national political consciousness", what components it should include, and what determinants it should determine. In particular, what is the role of political consciousness in the formation of a democratic society; how the transformation should take place. After all, overcoming a totalitarian political regime is impossible without a change in the minds of the people, without their active involvement in political decision-making, in the development of the state, in the organization of civil society. In fact, the question of studying the development of national and political consciousness of the population of the state is a dynamic process, as is the dynamic political system.

The modern rapid development of the information society has actively invaded the field of politics with its adjustments. Accordingly, modern information flows have an impact on the political consciousness of citizens and their ability to resist manipulative influences, fakes, information wars, which is a necessary component of national security. But no matter how 
perfect, no matter how detailed the mechanisms of political power, no matter how democratic and structured political institutions are, no matter how the laws of human existence in the new society do not correspond to their natural rights, without taking into account such an important factor as the level of political consciousness. The process of progression is impossible ${ }^{1}$.

The state of theoretical development of the problem. Therefore, back in the $90 \mathrm{~s}$ in the Ukrainian scientific space, research on the political consciousness of Ukrainian society began more and more actively. When such neologisms as "political hysteria", "apathy", "depression", etc. appear in the political vocabulary, the research of E. Golovakha and N. Panina on the manifestations of mass consciousness in political and social processes becomes important ${ }^{2}$. General theoretical questions of consciousness and existence of the nation are found in the studies of A. Kolodiy ${ }^{3}$. In turn, I. Kresina considers the Ukrainian national consciousness through the ethnopolitical approach and the relationship of political consciousness with political processes ${ }^{4}$. M. Popovych draws attention to the peculiarities of mythology in the public consciousness of post-communist Ukraine ${ }^{5}$.

In the early $2000 \mathrm{~s}$, a number of studies of various aspects of political consciousness, its types, varieties, and so on. Thus, the essence and conditions of formation of political consciousness in the process of state formation in Ukraine are investigated by S. Matviienkiv ${ }^{6}$. Problems of political consciousness of the Ukrainian society in the conditions of democratic transformation are considered by V. Demyanenko ${ }^{7}$, and factors of its formation in the specified context are defined by Yu. Rudenko ${ }^{8}$.

${ }^{1}$ Матвієнків С.М. Трансформація політичної свідомості в умовах становлення демократії в Україні: монографія. 2-е вид. допов. і переробл. Івано-Франківськ : HAIP, 2018. C. 6.

${ }^{2}$ Головаха Е., Панина Н. Социальное безумие: история, теория и современная практика. Київ : Абрис, 1994. 168 с.

${ }^{3}$ Колодій А. Нація як суб’єкт політики. Львів : Кальварія, 1997. 55 с.

4 Кресіна I. Українська національна свідомість і сучасні політичні процеси: (Етнополітичний аналіз). Київ : Вища школа, 1998. 392 с.

${ }^{5}$ Попович М. Міфологія в суспільній свідомості посткомуністичної України. Дух і Літера. 1998. № 3-4. С. 57-68.

${ }^{6}$ Матвієнків С.М. Політична свідомість: суть та умови їі формування в процесі державотворення в Україні : автореф. дис. ... канд. політ. наук : 23.00.02. Львів : Націон. ун-т ім. І. Франка. Львів, 2001. 19 с.

7 Дем'яненко В.М. Політична свідомість українського суспільства в умовах демократичної трансформації : дис. ... к. політ. н. : 23.00.02. Нац. акад. наук України, Ін-т політ. і етнонац. дослідж. Київ, 2003. 17 с.

8 Руденко Ю.Ю. Політична свідомість українського суспільства в трансформаційний період: чинники формування (політологічний аналіз) : дис. ... к. політ. н. : 23.00.02. АПН України, Ін-т вищ. освіти. Київ, 2003. 181 с. 
V. Yaroshenko explores the values of the political consciousness of young people as a driving component of political processes ${ }^{9}$.

Such a wide range of research suggests that such a political science category as "political consciousness" is not sufficiently studied and acquires new determinants, given the new variables that arise in the development of the political system of the state. Thus, the question of national consciousness of the population of Ukraine in the conditions of state independence is studied by G. Redkina ${ }^{10}$, and the role of mythological consciousness in understanding politics is revealed by Yu. Shaygorodsky ${ }^{11}$. Also, in modern political science, the issue of political consciousness and national consciousness is increasingly acquiring new approaches to the study of the problem. Thus, certain aspects of political and civic consciousness through the value dimension of historical forms of human existence are considered in his works V. Denisenko ${ }^{12}$.

In general, the scientific plane outlined several approaches to the study of theoretical and empirical factors of political and national consciousness: interdisciplinary, sociological, ethnopolitical, axiological. Modern global challenges to the development of society introduce new determinants of study of manifestations of political consciousness (in particular, in the national plane). Among these determinants, it is worth identifying a communication variable that requires new approaches to defining political consciousness. In this context, it is worth noting the developments of D. Arabadzhiev and T. Sergienko ${ }^{13}$, R. Kolisnichenko ${ }^{14}$, N. Ukhanova ${ }^{15}$ and others.

Thus, despite the fact that in Ukrainian political science there is a significant amount of research on various aspects of political and national consciousness, the question remains open. After all, there is no single

9 Ярошенко В. Формування гуманістичних цінностей у політичній свідомості молоді : автореф. дис. ... канд. політ. наук : 23.00.02. Одеса, 2002. 19 с.

${ }^{10}$ Редькіна Г. Національна свідомість населення України в умовах державної незалежності : автореф. дис. ... канд. політ. наук : 23.00.05. Нац. акад. наук України, Ін-т політ. і етнонац. дослідж. ім. І.Ф. Кураса. Київ, 2009. 15 с.

11 Шайгородський Ю. Політика: взаємодія реальності і міфу: монографія. Інститут політичних і етнонаціональних досліджень ім. І.Ф. Кураса НАН України. Київ : Знання України, 2009. 400 с.

12 Денисенко В. Ціннісні основи історичних форм буття людини. Вісник Львівського університету. Серія філософсько-політологічні студії. 2011. Вип. 1. С. 75-86.

13 Арабаджиєв Д., Сергієнко Т. Політична маніпуляція та інформаційно психологічна безпека в політичних відносинах. Політікус. 2020. Вип. 2. С. 36-43.

14 Колісніченко Р. Глобалістична свідомість людства: політологічний аналіз : монографія. Київ : ДП «Вид. дім «Персонал», 2017. 422 с.

15 Уханова Н. Маніпулювання масовою політичною свідомістю: інформаційнопсихологічний і правовий аспекти. Інформація і право. 2015. № 3 (15). С. 43-48. 
approach among researchers to the definition of the categories "political consciousness" and "national-political consciousness", their nature, types, relationship with political processes.

\section{Theoretical foundations of the study of political consciousness}

The transformation of modern Ukrainian society, new challenges for the politics of domestic and foreign policy, require new approaches to understanding the importance of the role of political consciousness of citizens for the development of statehood. Each new generation inherits a certain set of political knowledge, historical memory, political values and stereotypes that underlie political consciousness. The question arises: what should a modern healthy democratic society be like? How to overcome the problems of inequality, social poverty, xenophobia, cultural prejudices, various kinds of intolerant attitudes in society, the spread of hate speech, etc.? It is the study of the determinants of political consciousness, the peculiarities of its functioning and possible ways of transformation that can provide answers to the questions posed.

Political consciousness arose in antiquity as a response to the real need to comprehend such new phenomena as the state and state power. Political ideas of ancient thinkers (Plato, Aristotle, etc.) justified the need for a society of state transformations into a system of norms of human behaviour in the political space. Already in ancient times, political ideas and ideas form a specific autonomous system of spiritual phenomena as part of society ${ }^{16}$. Modern healthy democracy depends on the political consciousness of citizens, the ability to civic responsibility, activity, involvement in the political process. Thus, political consciousness is a set of knowledge and assessments, views and ideas of people about the political system of the state, its institutions and regime.

In order to better understand the subject of research, it is necessary to operationalize the basic concepts. It is worth paying attention to the peculiarities of the definition of "political consciousness" and "nationalpolitical consciousness". Among scientists there is no single approach to the definition of these concepts. Thus, the Political Science Encyclopedic Dictionary defines that political consciousness is the mediation of the reflection of the political life of society, the essence of which is the problems of power, formation, development and satisfaction of interests and needs of political actors ${ }^{17}$.

${ }^{16}$ Матвієнків С.М. Трансформація політичної свідомості в умовах становлення демократії в Україні : монографія. 2-е вид. допов. і переробл. Івано-Франківськ : HAIP, 2018. C. 37.

${ }^{17}$ Політологічний енциклопедичний словник / Упорядник В.П. Горбатенко ; за ред. Ю.С. Шемшученка, В.Д. Бабкіна, В.П. Горбатенка. 2-е вид., доп. і перероб. Київ : Генеза, 2004. С. 510. 
In the educational encyclopedic dictionary "Political Science" edited by N. Khoma, political consciousness is defined as a set of views and guidelines that characterize the attitude of people to the state, parties, socio-political organizations, political values and development goals, traditions and norms of political life; is a set of rational and emotionally sensitive, theoretical and empirical, value and normative, conscious and subconscious ideas of political actors about events, phenomena and trends related to issues of political power ${ }^{18}$.

Since political consciousness is formed by political practice, which acquires different characteristics and interpretations, some scholars propose to generalize the definition of political consciousness in separate approaches, as well as essential concepts.

Thus, R. Kolisnichenko, analysing different approaches to the definition of "political consciousness", notes that in general a wide variety of definitions of political consciousness should be combined into certain concepts of modern understanding of its essence:

- reflexive concept - political consciousness, mainly, deals with the reflexive "subjectivization" of politics;

- idealistic concept - political consciousness expresses a set of sensory and theoretical, rational and subconscious ideas of the individual about politics;

- complex concept - defines political consciousness as a set of knowledge, ideas, views, opinions, judgments, emotional states of the subjects of the political process ${ }^{19}$.

In turn, V. Voropaeva, exploring the socio-philosophical context of the metamorphosis of modern political consciousness in a crisis, identifies somewhat different approaches to the study of political consciousness:

- epistemological - includes empirical and theoretical political consciousness. At the first the direct, everyday practical political experience of the person is fixed; the second is a set of doctrines, ideas that arise on the basis of scientific research of the political life of society;

- sociological - highlights the political ideology; political psychology; mass and group consciousness;

- specific-historical - distinguishes types of political consciousness depending on the use of formational or civilizational approaches ${ }^{20}$.

18 Політологія: навчальний енциклопедичний словник довідник для студентів ВН3 I-IV рівнів акредитації / За наук. ред. д-ра політ. н. Хоми Н.М. [В.М. Денисенко, О.М. Сорба, Л.Я. Угрин та ін.]. Львів : «Новий Світ - 2000». С. 590.

${ }^{19}$ Колісніченко Р. Глобалістична свідомість людства: політологічний аналіз : монографія. Київ : ДП «Вид. дім «Персонал», 2017. С. 81. 
Thus, we see that political consciousness is organically connected with the psychological world view, is part of the political ontology, is based on theoretical views, which are an extensive system of concepts and doctrines. It is the political consciousness that acts as a regulator of political relations and can change in the process of long-term historical development or, conversely, in an accelerated time with the help of certain catalysts. As I. Servetsky and V. Redko note, political consciousness can be formed by means of "critical comprehension of socio-political reality, generalization of available information; awareness of the purpose of the party or political movement, joining the assessments and norms of the already formed political movement; emotional conviction in the justice of certain political ideals" 21 .

Given the number of definitions of the concept of "political consciousness" and the corresponding approaches to understanding this category, it should be noted that the structural definition of political consciousness is quite difficult. In the academic sphere, it is customary to distinguish the following types and levels of political consciousness:

- according to the functional approach to distinguish political and psychological (feelings, moods, motives, attitudes, beliefs, etc.), political and ideological (ideas, views, doctrines, concepts, theories), political action (conservative consciousness, liberal, reformist, radical, etc.) types of political consciousness ${ }^{22}$;

- by subjects - individual, group, class, mass, social, national consciousness;

- according to the epistemological approach, every day and theoretical political consciousness is distinguished.

And although a significant number of academic papers are devoted to the types and levels of political consciousness, but each new generation at different levels of functioning of political consciousness adds new meanings and manifestations. Political consciousness is closely connected with political processes, political relations, the political system of society, the state of education (including political), is an integral part of the political culture of society.

20 Воропаєва В.Г. Метаморфози сучасної політичної свідомості в умовах політичної кризи: соціально-філософський контекст. Гуманітарний вісник ЗДІА. 2014. № 57. С. 178-179.

21 Сервецький I., Редька В. Проблеми формування політичної свідомості громадян в умовах демократичного суспільства. Юридичний часопис Національної академії внутрішніх справ. 2012. № 1(3). С. 78-83.

${ }^{22}$ Політологічний енциклопедичний словник / Упорядник В.П. Горбатенко ; за ред. Ю.С. Шемшученка, В.Д. Бабкіна, В.П. Горбатенка. 2-е вид., доп. і перероб. Київ : Генеза, 2004. С. 511. 
B. Tsymbalisty notes the following factors that influenced the formation of the political culture of the Ukrainian people:

- centuries-old statelessness, in the lack of opportunity to gain experience in power, to be equal in relations with other peoples and to feel free to own their land;

- the dismemberment of Ukrainian territory and the inclusion of its parts in different states with different cultures, political systems, which led to psychological, domestic and political alienation between different parts of the Ukrainian people;

- multiple denationalization of the leading stratum of Ukraine in the XVI-XVII centuries. our boyar and noble strata united. In the XVIII-XIX centuries. descendants of Cossack officers Russified. In the $\mathrm{XX}$ century. the proletarian leading class was destroyed or for the most part served the interests of the Soviet-Russian Empire ${ }^{23}$.

In addition to historical facts that in one way or another influenced the formation of political culture and political consciousness of modern Ukrainian society, there are also factors of character that affect the formation of political consciousness of society. Such factors, for example, K. Bush includes:

1) external, which include the institutions of the political system, national and social groups, various informal associations, under the influence of which is the socialization of the individual;

2) internal, characterizing the mechanisms of world perception, analysis and decision-making, etc. The latter cover the needs, interests, spiritual values, individual psychological qualities of $\operatorname{man}^{24}$.

Thus, considering the political consciousness of Ukrainian society during the thirty years of independence, we can identify some factors that contributed to the transformation of political consciousness:

- 1991-2000 is a period of formation of Ukrainian statehood, characterized by two polar world views - "regret for lost ideals" and "faith in a better democratic society". But the economic and political crisis of this period led to rising inflation and the shadow sector, which in turn resulted in the criminalization of life. These factors were especially destructive for the political consciousness of citizens, because as M. Popovych noted, "under such conditions the population of Ukraine trusts the government, police, parliament, communists and nationalists even less than astrologers (the degree of trust in the latter in 1994-1996 is 17-18\%). The religiosity of

${ }^{23}$ Цимбалістий Б. Політична культура українців. Сучасність. 1994. № 3. С. 78-102.

${ }^{24}$ Буш К. Специфіка прояву політичної свідомості сучасної української молоді. Міжнародний науковий форум: сочіологія, психологія, педагогіка, менеджмент. 2013. Вип. 12. С. 107. 
society has grown quite rapidly: about two thirds of the population rely on God. They rely mainly on themselves and their loved ones"25.

- 2001-2010 - this period is characterized by increasing polarization of Ukrainian society. The political consciousness of citizens is characterized by a low level of trust in public authorities, local governments, the predominance of irrational and emotional factors in the implementation of political choices. In this context, Bush notes that one of the factors that significantly influenced the political consciousness was the events of the "Orange Revolution". The authority of the authorities was also undermined during the events of the winter and spring of 2001, when Ukraine found itself in a state of political crisis, which was associated with the murder of journalist G. Gongadze, when the investigation began to manifest itself negative phenomena in the upper echelons of power ${ }^{26}$. This decade is characterized by fluctuations in interest and involvement of citizens in political processes: economic crisis, permanent political instability, which caused a high level of social pessimism, negatively affected the political consciousness of Ukrainians, the development of democratic values and contributed to the partial return of paternalistic sentiments;

- 2011 to the present time - in this period the transformational processes of the political consciousness of the Ukrainian society are noted, the catalyst of which became the events of the Revolution of Dignity. Thus, N. Revenko notes that in previous years the political activity of the vast majority of Ukrainians was limited to participation in electoral processes and was almost invisible in the activities of public organizations, political parties, or mass political events. However, in the events of the Revolution of Dignity there was a mass participation of Ukrainian citizens in rallies, demonstrations and other actions. The authorities' refusal to join the Association Agreement with the EU caused a surge of activity in support of Ukraine's European integration strategy ${ }^{27}$.

Also, it should be noted that this decade is characterized by an increase in the level of national and political consciousness. The political consciousness of modern Ukrainian society is undergoing transformations not only in the direction of foreign policy guidelines, but also not a standard form of participation in state-building processes - volunteering (acquires a special surge during this period), various social projects (participation in

${ }^{25}$ Попович М. Міфологія в суспільній свідомості посткомуністичної України. Дух і Літера. 1998. № 3-4. С. 68.

${ }^{26}$ Буш К. Специфіка прояву політичної свідомості сучасної української молоді. Міжнародний науковий форум: соиіологія, психологія, педагогіка, менеджмент. 2013. Вип. 12. С. 109.

27 Ревенко Н. Політична свідомість та політична практика українського суспільства: взаємозв'язки та впливи. Сучасне суспільство. 2015. Вип. 1(1). С. 108. 
local government, social actions against violence), bullying, etc.). At the same time, communication progress has created conditions for new forms of political participation related to cyberspace and time (various messengers, social networks, chatbots). That is, in addition to the real political processes that affect the political consciousness of modern Ukrainian society, the virtual world of political reality is beginning to play an important role.

That is, the criterion for assessing the level of development of political consciousness is the degree, scale of political activity of members of society, their participation in the creation of material and spiritual goods. It is the practical behaviour of a person, his position, attitude to politics provide a reliable criterion for social change. Political consciousness is manifested not only through a system of their own political concepts, ideas. It also includes the ideas and feelings of many other forms of social consciousness. It is impossible to do without this at least because the purpose and results of political activity of groups of people, individuals need a material and legal basis in terms of their moral values and legal legitimacy ${ }^{28}$.

Thus, political consciousness is a holistic system of interconnected elements - values, mentality, historical memory, spiritual aspects of the people's existence, which are inextricably linked with the results of the objective process of development of society. The political consciousness of modern Ukrainian society, formed by historical preconditions, political and economic crises, remains ambivalent. During the period of independence, the political consciousness of Ukrainian society was influenced by certain stimuli that set new demands on the Ukrainian people regarding political reality and political participation.

It is possible to determine a direct relationship between the socioeconomic success of the state and the level of political consciousness of citizens. Not the least role here is played by the political education of the community and youth in particular. Political consciousness in its detailed study is able to anticipate political practice and help predict political processes. The main challenge facing the political consciousness of modern Ukrainian society is overcoming political ambivalence, overcoming the mythologizing of historical processes in the direction of objectivity, the desire to cultivate democratic values that would reflect the position of the whole nation. In this context, it is worth talking about the national and political consciousness of modern Ukrainian society.

${ }^{28}$ Матвієнків С.М. Трансформація політичної свідомості в умовах становлення демократії в Україні : монографія. 2-е вид. допов. і переробл. Івано-Франківськ : HAIP, 2018. C. 50. 


\section{Determining the determinants of national and political consciousness of modern Ukrainian society}

Modern Ukrainian society is in the process of developing civil society on the basis of democratic values and freedoms, rethinking the past political experience, the formation of national identity. All these challenges of modernity pose new challenges for the public consciousness, the need for its development from the individual to the representativeness of the whole nation. In the scientific space, the question still remains open: what should be the national and political consciousness of the modern Ukrainian people? What are its main determinants that contribute to its change? Various crisis situations can be important catalysts for the transformation of political consciousness.

Analysing the issue of crisis political situations, T. Lyashenko notes that approaches to the interpretation of crises are ambiguous. Understanding the crisis in the Soviet scientific literature was seen as a state of decline. Today, the political crisis, in particular, is interpreted as a transitional situation ${ }^{29}$.

In modern social and behavioural sciences there is no clear universal definition of "national-political consciousness", nor is there a single approach to understanding political consciousness and the nation. In scientific intelligence, we partially meet the definition of "national consciousness". For example, L. Kulishenko defines national consciousness as a category, the essence of which is the awareness of belonging to a certain nation (in identification with a certain people, nation), and accordingly, this category is based on the following features: language, culture, common history, mentality, territory, economy, political and legal institutions ${ }^{30}$.

National consciousness through the prism of socio-political activity is defined by G. Redkin, noting that this type of consciousness is primarily due to people's awareness of their unity, common origin, historical destiny, culture, a set of stereotypes of consciousness and behaviour, as well as civic and political traditions, interests, prospects for political development, common political institutions, rights and responsibilities, economic and social space, common citizenship ${ }^{31}$. This definition is more a definition of national-political consciousness.

In the Political Encyclopedic Dictionary, national consciousness is defined as a set of social, economic, political, moral, ethical, philosophical,

29 Ляшенко Т. Дослідження суспільно-політичного транзиту України вітчизняними вченими. Вісник Дніпропетровського університету. 2016. № 3. С. 47.

30 Кулішенко Л. Національна свідомість крізь призму світоглядних позицій українців. Світогляд - Філософія - Релігія : збірник наук. пр. 2011. № 1(1). URL: http://dspace.uabs.edu.ua/jspui/bitstream/123456789/5276/1/

31 Редькіна Г. Національна свідомість молоді України в умовах політичної кризи. Грані. 2015. № 11(1). С. 53. 
religious views, norms of behaviour, customs and traditions, values and ideals that reflect the characteristics of nations and nationalities. The basis of national consciousness is national self-consciousness ${ }^{32}$. Thus, national selfconsciousness can be defined as a certain set of values, ideals, ideas, knowledge, attitudes of national and ethnic communities about their place among other communities.

While the national-political consciousness is a certain system of clearly formed ideas (ideals, ideas, opinions, orientations) about the place of nations and peoples in the socio-political space based on awareness of their historical, cultural, religious, political identity, which determine the formation of sociopolitical behaviour and political ideology. The main task of national-political consciousness is to mobilize the masses for political collective identification for the sake of national development by determining kinship ties, common origins, a sense of common history and a specific culture. After all, without the revival of the Ukrainian ethnic nation, without fulfilling its political mission, it is impossible to develop the Ukrainian national and political consciousness.

Yu. Ivchenko believes that the national consciousness is historically formed in the process of nation-building, through the awareness of the representatives of the ethnic group of their origin and organic connection with their cultural roots, recognition of the original nature of the native culture, language, national characteristics, mentality and sense of national solidarity $^{33}$.

The following elements are clearly manifested in the highly developed national consciousness and self-consciousness:

- national identification, in a person's awareness of his belonging to a particular ethnic group, nation;

- knowledge of typical features, features of ethnicity or nation to which a person belongs, interest in ethnic, national features that are characteristic of other national communities;

- awareness of the unity of the historical past, present and future of their ethnic group, nation;

- clear ideas about the territorial community of the nation;

- awareness and effective attitude to the spiritual and material values of the nation, the need for personal work to enrich such values in their lives;

32 Політологічний енциклопедичний словник / Упорядник В.П. Горбатенко ; за ред. Ю.С. Шемшученка, В.Д. Бабкіна, В.П. Горбатенка. 2-е вид., доп. і перероб. Київ : Генеза, 2004. С. 390.

${ }_{33}$ Івченко Ю. Національна свідомість і патріотизм як чинники відродження Української держави. Прикарпатський юридичний вісник. 2017. Вип. 6(1). С. 20. 
- awareness of their own responsibility for the fate of the nation, its present and future ${ }^{34}$.

In general, the problematic field of formation and functioning of the national consciousness of modern Ukrainian society includes objective and subjective factors. The first include:

- regional, linguistic and cultural differences due to the historical past of Ukraine;

- violation of the ideological and value continuity of generations;

- disunity and incompleteness of the process of crystallization of the national elite;

- the lack of spiritual unity of society, a generalized basic system of values, which would be supported by society (reflecting its transitional state);

- lack of integrating ideas, projects, prospects;

- communicative openness of Ukrainian society in the conditions of media globalization and information wars.

Among the subjective factors should be outlined:

- low level of national self-consciousness of the Ukrainian elite, its inability to develop the ideological basis of national statehood;

- the use of political parties and movements of confrontational ideologies based on opposite value systems, speculation on ideological, interfaith, ideological contradictions of modern Ukrainian society;

- lack of purposeful state policy on the formation of national identity of citizens of Ukraine ${ }^{35}$.

The national-political consciousness of society cannot be formed compulsorily, for example, by public authorities, it can change depending on the results of state institutions. The national-political consciousness of modern Ukrainian society should be the result of the creation of a single Ukrainian spirituality, national values, a sense of responsibility for the future of their state, their region, community. The pursuit of democratic values is closely linked to civic responsibility and the ability to make political decisions. In this context, it is appropriate to quote S. Vonsovich: "Stereotypes of democratic centralism weigh on the understanding that democracy is not always combined with emotional comfort. You have to pay for the right to choose with responsibility, for freedom - with uncertainty,

34 Кулішенко Л. Національна свідомість крізь призму світоглядних позицій українців. Світогляд - Філософія - Релігія : збірник наук. пр. 2011. № 1(1). URL: http://dspace.uabs.edu.ua/jspui/bitstream/123456789/5276/1

${ }^{35}$ Матвієнків С.М. Трансформація політичної свідомості в умовах становлення демократії в Україні : монографія. 2-е вид. допов. і переробл. Івано-Франківськ : HAIP, 2018. C. 186. 
for equality of opportunity - with a critical assessment of your own abilities" $" 36$.

As is known, national identity, national idea, and national identity are of fundamental importance for the formation of national consciousness mentality, national psychological complexes. But, in our opinion, it is worth considering such an important factor as the collective historical memory, which, according to O. Tregub, is always due to interest; is subjective, which is manifested in different views on the same events; determined by emotionality, heredity and continuity; may have a personalized character, because in the memory of nations are usually engraved images of genius figures - rulers, politicians and cultural figures, military leaders, as well as the most significant, groundbreaking events for the nation ${ }^{37}$.

Considering the moment of "awareness" of an individual or a certain group of their identity, it is worth talking about mental activity in the field of "conscious". It is quite difficult to determine what is said in the realm of the "unconscious". That is, the question of the functioning of national-political consciousness at the unconscious level remains poorly studied.

In general, we can distinguish the following levels of national identity:

a) low (often subconscious) - emotionally alienated empathy for their own unity with other members of the ethnic community (ethnic identity);

b) high - rational, deep awareness of nationality (national identity) $)^{38}$.

Scientific discussion on the levels of national consciousness, offers to consider the national consciousness in the horizontal and vertical aspects. The horizontal aspect of national consciousness means the level of national consciousness at which the nation is given priority to recognize themselves, their interests and goals, which allows them to compare their "I" with other communities, while developing a cognitive attitude to the set conditions of their existence. In turn, the vertical aspect allows us to trace the foundations of the national, taken in its historical, psychological, culturological relations.

Considering the components of national consciousness in terms of a systems approach, V. Karlova notes the following groups of elements:

- national integration - awareness of territorial, political, economic, cultural and linguistic community;

${ }^{36}$ Вонсович С. Розвиток трансформаційних процесів українського суспільства крізь призму політичної свідомості. Проблеми сучасної психологї. 2011. Випуск 13. C. 35 .

37 Трегуб О. Історична пам'ять як засіб мобілізації національної свідомості. Магістеріум. Політичні студії. 2008. Вип. 31. С. 27-28.

38 Матвієнків С.М. Трансформація політичної свідомості в умовах становлення демократії в Україні : монографія. 2-е вид. допов. і переробл. Івано-Франківськ : HAIP, 2018. C. 180. 
- national (ethnic) self-knowledge, national and ethnic identity, ethnic identity, dual ethno national identity - awareness of a common historical destiny, cultural, psychological identity and uniqueness, national (ethnic stereotypes); knowledge of the moral virtues of the national (ethnic) community;

- national values, national interests, national idea;

- interethnic comparison - the nation's self-assessment of itself and the assessment of other peoples, ideas about the nation's own role and status in the world community, the nation's contribution to the general civilizational progress of mankind;

- national feelings, moods, experiences - an emotional component that contains elements that establish the connection of the individual with the national (ethnic) community: patriotism, sacrifice in the name of national interests, civic duty, national dignity, respect for the past, veneration of national symbols, shrines, etc. ${ }^{39}$

As we can see, there is a fairly wide range of definitions of national and political consciousness. There is a discussion among scholars about the defining features of national-political consciousness, its components and levels. The issue of what can become a motivational impetus for the development of national identity, political consciousness, civic responsibility, and information security also remains unresolved. We can agree with the opinion of N. Efteni that "the motivational block of political consciousness is filled with political interests, needs, values, goals, attitudes and beliefs that motivate people to certain political behaviour, push to influence changes in society" ${ }^{\circ 0}$. But it is necessary to understand what determinants should determine this motivational block. Therefore, the determinants of national and political consciousness of modern Ukrainian society include the following factors:

- emotional-educational - may include irrational (sensory-emotional) means of forming the national-political consciousness of citizens: nationalpatriotic education, which should include modern real measures, and not have a declarative nature. May include receiving political or civic education for people of different ages;

- identification has two levels - regional and national. The first involves motivating citizens to identify with a particular region or community. Motivation can be both cultural and educational events and the creation of a

${ }^{39}$ Карлова В. Національна самосвідомість: сутність, поняття та зміст у контексті сучасних дослідницьких підходів. Державне управління: теорія $i$ практика: електрон. наук. фах. вид. 2009. № 2. URL: http://www.academy.gov.ua/ej/ej10/ zmist.htm

40 Єфтені Н. Особливості формування політичної свідомості. Політичне життя. 2019. № 4. С. 68 . 
coat of arms, $\log$ o or even a brand of the territory with the active involvement of citizens in cooperation. At the national level, these should be measures that form in citizens a stable connection with the historical past, a clear definition of ways to national unity in the present and a proposal for a strategy for the development of the national idea in the future;

- socio-political - in this category the motivational block should include the development of local democracy, involvement of citizens in political decision-making, active implementation of social partnership, etc. The low level of national and political consciousness of modern Ukrainian society is due to the distrust of citizens in the activities of both central government and local government, which includes the neglect of public authorities opportunities to interest citizens in their activities; lack of knowledge and skills necessary for active participation of citizens in decision-making processes; disinterest of the young generation in the work of public authorities, etc.;

- information and communication - is determined by the fact that modern media and communication can be a significant stimulus to the development of national and political consciousness of citizens, but provided that they leave the field of political influence and the creation of independent, objective media that adhere to fundamental democratic values;

- economic - this factor has a direct impact on the development of national and political consciousness of citizens, because until the basic vital needs of citizens are met, we can talk about national unity or the development of national and political consciousness only in theoretical terms. As the experience of Ukrainian society shows, various economic crises have only deepened the political inertia of citizens.

Thus, the national-political consciousness of modern Ukrainian society is on the path of transformation from the post-totalitarian to the democratic level. This process should include the reproduction of Ukrainian spirituality, national unity, the creation of a system of Ukrainian national values, the formation of the political sphere of ethnic components of public consciousness. All these aspects must be implemented in a democratic way, taking into account the national education of ethnic minorities, which includes knowledge of the state language, culture, customs and traditions.

\section{CONCLUSIONS}

The national and political consciousness of modern Ukrainian society is in a difficult period of transformation. The main features of the modern national-political consciousness of Ukrainians remain: ambivalence, in recognition as equivalent of directly opposite value orientations; low level of political and social activity and deportation of the population; low level of consolidation and identification of modern Ukrainian mass political 
consciousness; almost no sense of national unity, the need for strong unity of all members of the community to ensure their own security and well-being; national nihilism is still present and regional specifics remain relevant; political culture is still based on mythologizing and stereotyping.

Given the outlined range of problems and despite the rather significant achievements of research of political consciousness in the scientific field, the problem outlined in the study needs further study. In particular, in aspects of the formation of national consciousness in the development of the modern information society; overcoming the indifference of young people to the political life of the country; features of the formation of national psychology and national ideology, etc.

In the process of research, the concept of "national-political consciousness" is defined as a certain mobilizing system of ideas, ideals, ideas, thoughts, orientations on the place of nations and peoples in the socio-political space. These system of ideas should be formed on the basis of awareness of their historical, cultural, religious, political identity, which determine the main aspects of socio-political behaviour and political ideology. Motivational determinants of the development of national-political consciousness of modern Ukrainian society should be emotional-educational, identification, sociopolitical, information-communication and economic groups of factors. After all, the national and political consciousness of Ukrainian society is an integral part of the development of statehood. Its development must take into account global change, focus on democratic values and national unity, because the energy of political consciousness under the influence of destructive factors can generate arbitrariness, violence, despotism and other forms of anti-democracy in the political life of society. National-political consciousness is determined not only by national symbolism, it is a complex fragment of the spiritual activity of the people.

\section{SUMMARY}

The urgency of studying the problems of formation of modern political consciousness is determined in the article; the essence of political consciousness as a process of reflection of political reality is revealed; the mutual influence of the national consciousness of citizens and the current political situation in Ukraine is analysed; an attempt was made to interpret the national-political consciousness as an integrating force in the process of state formation; it is proved that the state of political consciousness significantly influences the formation of the political system, the peculiarities of the political regime, the political behaviour of citizens. National consciousness is one of the most important factors in the formation of a political nation, the sustainable development of the political system, the legitimation of state institutions. Ukraine has not yet formed a full-fledged 
political nation with clearly defined national interests, on which there would be a consensus among both the elite and the citizens. Priorities in the formation of national consciousness of citizens of modern Ukraine are: definition of the system of basic values, development of humanitarian policy (historical memory of the Ukrainian people, linguistic unity of society, common information and cultural space, cultural policy), state ethnic national policy of Ukraine and patriotic education.

\section{REFERENCES}

1. Арабаджиєв Д., Сергієнко Т. Політична маніпуляція та інформаційно психологічна безпека в політичних відносинах. Політікус. 2020. Вип. 2. С. 36-44. DOI https://doi.org/10.24195/2414-9616-2020-2-36-43

2. Буш К. Специфіка прояву політичної свідомості сучасної української молоді. Міжнародний науковий форум: соиіологія, психологія, педагогіка, менеджмент. 2013. Вип. 12. С. 103-110.

3. Вонсович С. Розвиток трансформаційних процесів українського суспільства крізь призму політичної свідомості. Проблеми сучасної психологіï. 2011. Випуск 13. С. 30-39.

4. Воропаєва В.Г. Метаморфози сучасної політичної свідомості в умовах політичної кризи: соціально-філософський контекст. Гуманітарний вісник ЗДІА. 2014. № 57. С. 175-191.

5. Головаха Е., Панина Н. Социальное безумие: история, теория и современная практика. Киев : Абрис, 1994. 168 с.

6. Дем'яненко В.М. Політична свідомість українського суспільства в умовах демократичної трансформації : дис. ... к. політ. н. : 23.00.02. Нац. акад. наук України, Ін-т політ. і етнонац. дослідж. Київ, 2003. 17 с.

7. Денисенко В. Ціннісні основи історичних форм буття людини. Вісник Львівського університету. Серія філософсько-політологічні студії. 2011. Вип. 1. С. 75-86.

8. Єфтені Н. Особливості формування політичної свідомості. Політичне життя. 2019. № 4. C. 66-70. DOI: https://doi.org/10.31558/25192949.2019.4.10

9. Івченко Ю. Національна свідомість і патріотизм як чинники відродження Української держави. Прикарпатський юридичний вісник. 2017. Вип. 6(1). С. 18-21.

10. Карлова В. Національна самосвідомість: сутність, поняття та зміст у контексті сучасних дослідницьких підходів. Державне управління: теорія і практика: електрон. наук. фах. вид. 2009. № 2. URL: http://www.academy.gov.ua/ej/ej10/zmist.htm

11. Колісніченко Р. Глобалістична свідомість людства: політологічний аналіз : монографія. Київ : ДП «Вид. дім «Персонал», 2017. $422 \mathrm{c}$. 
12. Колодій А. Нація як суб'єкт політики. Львів : Кальварія, 1997. 55 с.

13. Кресіна I. Українська національна свідомість і сучасні політичні процеси: (Етнополітичний аналіз). Київ : Вища школа, 1998. 392 с.

14. Кулішенко Л. Національна свідомість крізь призму світоглядних позицій українців. Світогляд - Філософія - Релігія : збірник наук. пр. 2011. № 1(1). URL: http://dspace.uabs.edu.ua/jspui/bitstream/ $123456789 / 5276 / 1 /$

15. Ляшенко Т. Дослідження суспільно-політичного транзиту України вітчизняними вченими. Вісник Дніпропетровського універcumemy. 2016. № 3. С. 46-57.

16. Матвієнків С.М. Політична свідомість: суть та умови іiі формування в процесі державотворення в Україні : автореф. дис. ... канд. політ. наук : 23.00.02. Львів. націон. ун-т ім. І. Франка. Львів, 2001. 19 c.

17. Матвієнків С.М. Трансформація політичної свідомості в умовах становлення демократії в Україні : монографія. 2-е вид. допов. і переробл. Івано-Франківськ : НАIP, 2018. 252 с.

18. Політологічний енциклопедичний словник / Упорядник В.П. Горбатенко; За ред. Ю.С. Шемшученка, В.Д. Бабкіна, В.П. Горбатенка. 2-е вид., доп. і перероб. Київ : Генеза, 2004. 736 с.

19. Політологія: навчальний енциклопедичний словник довідник для студентів ВНЗ I-IV рівнів акредитації / За наук. ред. д-ра політ. н. Хоми Н.М. [В.М. Денисенко, О.М. Сорба, Л.Я. Угрин та ін.]. Львів : «Новий Світ - 2000». 779 с.

20. Попович М. Міфологія в суспільній свідомості посткомуністичної України. Дух і Літера. 1998. № 3-4. С. 57-68.

21. Ревенко Н. Політична свідомість та політична практика українського суспільства: взаємозв'язки та впливи. Сучасне сусnільство. 2015. Вип. 1(1). С. 104-115.

22. Редькіна Г. Національна свідомість молоді України в умовах політичної кризи. Грані. 2015. № 11(1). С. 51-55.

23. Редькіна Г. Національна свідомість населення України в умовах державної незалежності : автореф. дис. ... канд. політ. наук : 23.00.05. Нац. акад. наук України, Ін-т політ. і етнонац. дослідж. ім. І.Ф. Кураса. Київ, 2009. 15 с.

24. Руденко Ю.Ю. Політична свідомість українського суспільства в трансформаційний період: чинники формування (політологічний аналіз) : дис. ... к. політ. н. : 23.00.02. АПН України, Ін-т вищ. освіти. Київ, 2003. 181 с.

25. Сервецький I., Редька В. Проблеми формування політичної свідомості громадян в умовах демократичного суспільства. Юридичний 
часопис Національної академії внутрішніх справ. 2012. № 1(3). C. $78-83$.

26. Трегуб О. Історична пам'ять як засіб мобілізації національної свідомості. Магістеріум. Політичні студї. 2008. Вип. 31. С. 25-29.

27. Уханова Н. Маніпулювання масовою політичною свідомістю: інформаційно-психологічний і правовий аспекти. Інформація $і$ право. 2015. № 3 (15). С. 43-48.

28. Цимбалістий Б. Політична культура українців. Сучасність. 1994. № 3. С. $78-102$.

29. Шайгородський Ю. Політика: взаємодія реальності і міфу : монографія. Інститут політичних i етнонаціональних досліджень ім. І.Ф. Кураса НАН України. Київ : Знання України, 2009. 400 с.

30. Ярошенко В. Формування гуманістичних цінностей у політичній свідомості молоді: : автореф. дис. ... канд. політ. наук : 23.00.02. Одеса, 2002. 19 с.

\section{Information about the authors:}

Matviienkiv S. M.,

Candidate of Political Sciences, Associate Professor at the Department of Political Institutions and Process

Vasyl Stefanyk Precarpathian National University 57, Shevchenko str., Ivano-Frankivsk, 76018, Ukraine

Lushahina T. V., Candidate of Political Sciences, Senior Lecturer at the Department of Political Sciences Petro Mohyla Black Sea National University 10, 68 Desantnykiv str., Mykolaiv, 54000, Ukraine 